\title{
Correction to: Deciphering the genetic and epidemiological landscape of mitochondrial DNA abundance
}

\author{
Sara Hägg ${ }^{1}$ Juulia Jylhävä ${ }^{1}$ Y Yunzhang Wang ${ }^{1} \cdot$ Kamila Czene $^{1} \cdot$ Felix Grassmann ${ }^{1,2}$ (1)
}

(c) The Author(s) 2021

\section{Correction to: Human Genetics \\ https://doi.org/10.1007/s00439-020-02249-w}

In the original article, the acknowledgement section is incorrectly published. The correct acknowledgement is

The computations and data handling were enabled by resources provided by the Swedish National Infrastructure for Computing (SNIC) at UPPMAX, Uppsala University, partially funded by the Swedish Research Council through grant agreement no. 2018-05973.

This research has been conducted using the UK Biobank Resource under Application Number 22224.

The original article can be found online at https://doi.org/10.1007/ s00439-020-02249-w.

Felix Grassmann

felix.grassmann@ki.se

1 Department of Medical Epidemiology and Biostatistics, Karolinska Institutet, Nobels väg 12A, 17165 Stockholm, Sweden

2 Institute of Medical Sciences, University of Aberdeen, Aberdeen, UK
Open Access This article is licensed under a Creative Commons Attribution 4.0 International License, which permits use, sharing, adaptation, distribution and reproduction in any medium or format, as long as you give appropriate credit to the original author(s) and the source, provide a link to the Creative Commons licence, and indicate if changes were made. The images or other third party material in this article are included in the article's Creative Commons licence, unless indicated otherwise in a credit line to the material. If material is not included in the article's Creative Commons licence and your intended use is not permitted by statutory regulation or exceeds the permitted use, you will need to obtain permission directly from the copyright holder. To view a copy of this licence, visit http://creativecommons.org/licenses/by/4.0/.

Publisher's Note Springer Nature remains neutral with regard to jurisdictional claims in published maps and institutional affiliations. 